\title{
Correlation between gratitude and perceived social support in parents of children with intellectual disability
}

\author{
Alfina Dewi Hermansyah \\ Department of Psychology \\ Hasanuddin University \\ Indonesia \\ alfina.dewihermansyah@gmail.com
}

\author{
Umniyah Saleh \\ Department of Psychology \\ Hasanuddin University \\ Indonesia
}

\author{
Nirwana Permatasari \\ Department of Psychology \\ Hasanuddin University \\ Indonesia
}

\begin{abstract}
The present study aimed to explore the relationship between gratitude and perceived social support in parents of children with intellectual disability at Makassar. There were 40 participants selected using purposive random sampling. The criteria of selecting participants are parents of children with moderate or severe intellectual disability who are educated in formal/non-formal education. Participants were asked to complete gratitude scale and perceived social support scale. Rank spearman correlation indicated that there was a significant positive correlation between gratitude and perceived social support. Keywords - component; formatting; style; styling;
\end{abstract}

\section{INTRODUCTION}

Parents as the main figures to care, nurture and meet children's need from prenatal until adulthood. Among parents, some of parents are blessed to have children with special needs. Children with special needs are children who are significantly different in some important dimensions of their function, including physical, cognitive or social which impede their goal accomplishment and potential. These special needs including deafness, blindness, speech impairment, disability, mental retardation, emotional disturbance, and gifted children with high intelligence [1]

Intellectual disability is one type of special need also known as mental retardation and down syndrome. There is no exact number of how many children with intellectual disability, but it can be estimated that the number is increasing from year to year. Data from Indonesia's central bureau of statistic in 2006 showed there were $0.7 \%$ of Indonesia's population or about 2.8 million people are disabled [2]. In 2007, it was reported that number of people with intellectual disability in Indonesia has reached 6.6 million people or $3 \%$ from 220 million people of total population. [3]. However, education for children with special needs cannot reach all children with disabilities. Data from the ministry of education in 2008 showed that only 38,545 of people with intellectual disability attending special education [4].
Parents can reacts differently upon knowing that their children have special abilities. Hardman, Drew, and Egan state that parents dealing with special needs children experience dynamic of feelings, ranging from shock, realization, defensive retreat, and acknowledgment [5]. In fact, there are parents who experience depression [6] [7] [8]. Parents who have children with disability desperately need support from others from their spouse, family, friends, or even from the environment. In general, availability of social support for parents will improve their psychological well-being and quality of life [9]. There are various forms of social support that can be accessed by families with children with special needs, including from nuclear families, extended families, support groups, family support groups, and internet resources. However, in reality, not all parents perceive that they get social support they need [10] [11].

Social support perceived by individuals can be varied. Parents who feel support from other person perceive that they are not alone and are grateful of the support they received [12]. Perceived social support can be developed through gratitude [13]. Research conducted by Wood, Maltby, Stewart, Linley, and Joseph found that gratitude can lead to a more supportive development environment, and increased awareness of perceived social support [4]. Other studies conducted by Wood, Maltby, Gillet, Linley, and Joseph on the role of the relationship between social support, stress, and depression found that gratitude led to increased social support, and reduced stress and depression [13]. In addition, gratitude is also associated with emotional and instrumental social support [15].

This paper aims to investigate the relationship between gratitude and perceived social support in parents of children with intellectual disability. Theoretically, this research is expected to contribute to psychology associated with positive psychology, especially about gratitude, and for family psychology, especially in the field of social support to families of children with intellectual disability. Practically, this research is expected to: (a) provide knowledge and information to 
families of children with mental retardation on the importance of social support to parents; (b) assisting parents of children with mental disability to acknowledge the importance of gratitude in self; and (c) providing assistance to parents of children with mental retardation in order to make changes from perception of meaningless life and negative emotions to more positive view regarding circumstances that happen

\section{EASE OF USE}

\section{A. Gratitude}

Peterson and Seligman define gratitude as a feeling of thankfulness and happiness as the response of a gift received, in which the gift is received as a benefit from person or as an event of peace. [16] In addition, gratitude produces a pleasant state and is associated with positive emotions, including contentment, happiness, pride, and hope [17]. Gratitude is divided into two type, which are (a) personal gratitude which is gratitude directed toward a certain person who has benefited himself, and (b) transpersonal gratitude, which is gratitude addressed to God, greater power, or to the universe [16].

Gratitude is divided into four dimensions which are gratitude intensity, gratitude frequency, gratitude span, and gratitude density. Intensity dimension refers to the strength of grateful character. A person with high gratitude intensity will be more grateful when experiencing positive events. People with high gratitude frequency will have a grateful feeling several times a day that can appear in simple things or polite behavior. On the span dimension, individuals with a strong grateful character will feel more grateful in more aspects of their lives whilst in gratitude density, individuals with a strong grateful character, will have a grateful sense to greater number individuals.

\section{B. Perceived Social Support}

Perceived social support is expressed as the perception or experience of individuals that they have social support from others when they need it [18]. Perceived social support is also defined as the acceptance of support provided by closest others, including family support, friendship support, and support of meaningful people around [19]. Social support consists of three components: (a) family support, which is the assistance provided by family member; (b) friend support is the help provided by a friend; and (c) significant other support which is the assistance provided by other meaningful person, including neighbors [19].

There are four types of social support: emotional or esteem support; tangible or instrumental support; informational support; and companionship support [20]. In providing a social support, individuals are influenced by (a) empathy in which individuals provide assistance to the distress others in order to anticipate emotions and thus motivated to reduce distress and improve the well-being of others; (b) norms and social values that guide individuals to fulfill obligations in life; and (c) social exchanges where there is a reciprocal relationship between social behavior, love, service, and information [21].

\section{Parents of Children with Mental Retardation}

According to KBBI (Indonesian dictionary), parents are biological father and mother. Parents are men and women who are bound in marriage and are willing to take responsibilities as a father and mother of their children [22].

Mental disability also known as mental retardation [1]. This term refers to children with below average intelligence [23]. AAMR in Mangunsong [1] states that mental retardation indicates a significant limitation in intellectual functioning and adaptive behavior embodied in conceptual, social, and practical which occurred before the age of 18 years. Intellectually disabled children have two important points: mental retardation includes not only to intellectual functions, but also adaptive behavior. Both intellectual functions and adaptive behavior can be developed in individuals with mental retardation. Intellectual function is determined by intelligence tests that refer to abilities related to academic performance. Adaptive ability refers to the ability of the conceptual, social, and practical capabilities that individuals learn to function in everyday life.

Children with mental retardation experience development delay compare to average children with no mental retardation. Although the child with mental retardation has the same mental age with children with no mental retardation, children with mental retardation have a slower development, ranging from physical, motor, cognitive, and language development. For physical development, children with mental retardation need to be trained specifically for basic movement skills. In cognitive development, children with mental retardation have slower learning speeds, slower response speeds (accuracy), as well as shorter short-term memory. However, no difference is found in long-term memory in children with and with no mental retardation. In language development, children with mental retardation have impaired articulation, sound quality, and rhythm. The development of the morphology and development of semantic in children with mental retardation are slower than children with no mental retardation [1].

Mangunsong [1] suggests characteristics of children with mental retardation based on the classification by APA are:

- Mild mental retardation: children do not show significant differences with normal children, except slightly slower than the average normal child and has shortcomings in terms of strength, speed, and coordination, as well as health problems.

- Moderate mental retardation: children have congenital physical abnormalities and experience many social problems.

- Severe mental retardation : children have poor physical condition, health problems and speech impairment.

- Profound mental retardation: children have more serious problems than mild, moderate, and severe mental retardation. These problems with physical condition, language, intelligence, educational programs, and limited social interactions. 


\section{METHOD}

\section{A. Participants}

The population in this study are parents who have children with mental retardation in Makassar. Participants were selected by purposive sampling which was obtained by visiting several therapy sites and special needs school. Participants in this study was selected based on several criteria: parent of either father and/or mother of children with mental retardation who lived in Makassar; the mentally retarded children are educated in formal and/or informal education; the mentally retarded children is classified as moderate, severe and profound mental retardation. There were 40 participants, participated in this study, of whom 39 were parents of children with moderate mental retardation and 1 parent of child with severe mental retardation. There were 119 men and 21 women participated in this study.

\section{B. Procedures}

Data collection was conducted by distributing questionnaire to parents who bring their children to therapy and by asking teachers in special needs schools to distribute the questionnaires.

\section{Measures}

To measure gratitude, a Likert scale instrument was constructed by investigator based on theory of gratitude by Peterson and Seligman [16]. Accordingly, there were four aspects to be measured which are: intensity, frequency, density, dan span. Confirmatory factor analysis was used to examine instrument' validity and Cronbach's alpha for reliability analysis. It was found that reliability of this instrument was .964 .

To measure perceived social support, an instrument was constructed by investigator based on social support theory by Zimet, Dahlem and Farley [19]. This scale was consisted of three aspects of social support: family support, friends support, and significant other support [19]. Validity analysis was conducted by confirmatory factor analysis and reliability analysis with Cronbach's alfa which show .960

\section{RESULT}

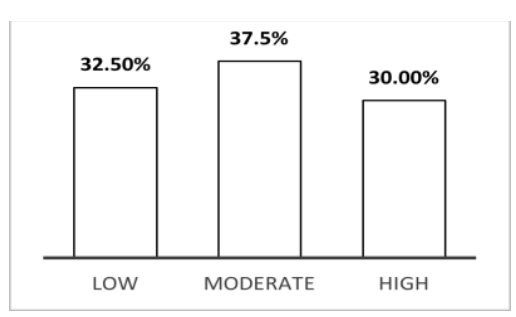

Fig. 1. Description of gratitude

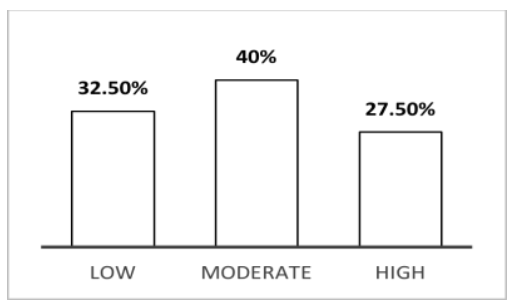

Fig. 2. Description of Perceived Social Support

TABLE I. NONPARAMETRIC CORRELATIONS

\begin{tabular}{ll}
\hline Correlation Coefficient & .834 \\
Sig. (2-tailed) & .000 \\
$\mathbf{N}$ & 40 \\
\hline
\end{tabular}

As can be seen from Fig. 1 and Fig. 2, most parents of children with mental retardation have moderate level of gratitude $(37.5 \%)$ and moderate level of perceived social support (40\%). However, there are also parents with low level of gratitude $(32.5 \%)$ and low level of perceived social support $(32.5 \%)$.

Table I presents Rank Spearman correlation shows a significant positive correlation between gratitude and perceived social support $r s=.834, p<.05$. This correlation coefficient indicated that there is a strong positive correlation between gratitude and perceived social support, and thus it can be inferred that the higher gratitude of a parents, the higher perceived social support. Vice versa, the lower parents' gratitude, the lower perceived social support.

\section{DISCUSSION}

The first set of analysis examined the description of gratitude and perceived social support in parents of children with mental retardation. From the result, it can be seen that most parents have moderate level of gratitude and perceived social support. However, there are parents with low gratitude and perceived social support. Low level gratitude indicates that parents are not optimal in showing the grateful behavior in various situations, lack of positive appreciation and thankfulness for everything they have, such as family, health, and jobs, as well as friends and people who provide support in taking care of their children.

Low level of perceived social support indicates that parents perceive less support and assistance from family, friends, and significant others. Pierce et al. state that spouse who does not receive support from their spouse will be more to involved in a conflict [18]. Moreover, they are more likely to search support from another person, and less likely to have a good mental health.

The second state of analysis examined the relationship between gratitude and perceived social support. Rank Spearman correlation shows a significant positive correlation 
between gratitude and perceived social support ( $\mathrm{rs}=.834$, $\mathrm{p}<.05)$. This result is similar to previous study by Wood et al. that propose gratitude is correlated with perceived social support [13]. There are several possible explanations for this result. Firstly, according to Lakey and Drew, gratitude can develop perceived social support [14]. Secondly, gratitude can develop supportive environment and thus result in higher awareness of social support [13]. Thirdly, gratitude is associated with perceived social support where family support mediate the relationship between other variables, such as selfesteem dan life satisfaction [24]. Lastly, gratitude is related to emotional and instrumental social support [15].

With regard to method in obtaining data, it is plausible that a number of limitations may influenced the results obtained. Data collection was conducted by asking teachers in special needs schools to distribute the questionnaire, which might distort participants responds'. Investigator did not have direct contact with participants during the questionnaire completion. As such, this study findings must be interpreted cautiously. Future study with more participant and more prudent data collection is suggested to be conducted.

\section{CONCLUSION}

This study set out to better understand gratitude and perceived social support in parents of children with mental retardation, also to examine the relationship between gratitude and perceived social support. This study has found that most parents had low to moderate level gratitude and social support. This result indicated that most parents have not been in optimal level of gratitude, which means that they have not shown a consistent behavior of thankfulness and positive appreciation of what they have receive. Furthermore, a low to moderate level of perceived of social support revealed that most parents less aware of the support and assistance provided by family, friends and significant others. The second major findings was that there was a significant positive correlation between gratitude and perceived social support, $r s=.834, p<.05$. This result confirms previous findings and contributes additional evidence that suggests gratitude is correlated with perceived social support.

\section{REFERENCES}

[1] F. Mangunsong, Psikologi dan Pendidikan Anak Berkebutuhan Khusus Jilid Kesatu Edisi 2014. Depok: LPSP3UI, 2014

[2] R.P. Rini. "Hubungan Antara Tingkat Pendidikan Orang Tua dengan Tingkat Kemandirian Anak Retardasi Mental Dalam personal Hygiene di SDLB Negeri Colomadu.” Naskah Publikasi, Fakultas Ilmu Kesehatan Program Studi Keperawatan Universitas Muhammdiyah Surakarta, 2012

[3] Heru. "Tunagrahita di Indonesia Capai 6,6 Juta Orang."Internet: http://antaranews.com/berita/83721/tunagrahita-di-indonesia-capai-66juta-orang, Nov, 27, 2007, [Feb. 25, 2016]

[4] Sindo. (2008). Kurikulum Khusus Penyandang Autis. Internet: http://lifestyle.okezone.com/read/2008/05/17/27/110062/kurikulumkhusus-penyandang-autis, May 17, 2008 [ Jun. 26, 2016]

[5] M.L. Hardman, C.J. Drew, and M. Egan. Human Exceptionality Society, School, and Family. Boston: A Pearson Education Company, 2002

[6] I. Arijanto. "Derajat Depresi dan Faktor-faktor yang Mempengaruhinya pada Orang Tua Anak Berkebutuhan Khusus di Komunitas Percik Insani Bandung. “Jurnal Universitas Padjajaran, vol. 10,2008.
[7] M.B. Olsson, and C.P. Hwang, C.P. "Depression in Mothers and Fathers of Children with Intellectual Disability." Journal of Intellectual Disability Research, vol. 45, pp.535-543, 2001,

[8] M.H. Bornstein. Handbook of Parenting Volume 1 Children and Parenting. Mahwah, New Jersey: Lawrence Erlbaum Associates Publishers, 2002

[9] N. Hidayati. "Dukungan Sosial bagi Keluarga Anak Berkebutuhan Khusus.” INSAN, vol.13, pp.12-20, 2011.

[10] D. Miranda. "Strategi Coping dan Kelelahan Emosional (Emotional Exhaustion) pada Ibu yang Memiliki Anak Berkebutuhan Khusus (Studi Kasus di Rumah Sakit Jiwa Daerah Atma Husada Mahakam, Samarinda, Kalimantan Timur). "ejournal Psikologi, vol. 1, pp.123-135, 2013

[11] Contact a family, "contact for families with disabled children," 22 August 2016. [Online]. Available: https://contact.org.uk/media/381636/forgotten_isolation_report.pdf.

[12] A. Sequenzia, "Ollibean," 2016 August 2016. [Online]. Available: http://ollibean.com/privacy-versus-popularity/.

[13] A. Wood, J. Maltby, P. Linley and S. Joseph, "A social cognitive model of trait and state level og gratitude," Emotions, vol. 8, no. 2, pp. 281-290, 2008.

[14] A. Wood, J. Maltby, R. Gillet, P. Linley and S. Joseph. "The Role of Gratitude in the Development of Social Support, Stress, and Depression Two Longitudinal Studies." Journal of Research in personality vol.42, pp. $854-871,2018$

[15] A. Wood, J. Maltby, P. Linley and S. Joseph,. "Coping Style As A Psychological Resource of Grateful People." Journal of Social and Clinical Psychological, vol. 26, pp.1067-1093, 2007

[16] C. Peterson, C. and M.E.P. Seligman,. Character Strengths and Virtues: A Handbook and Classification. New York: Oxford University Press, 2004

[17] C. R. Snyder and S.J. Lopez. Handbook of Positive Psychology. New York: Oxford University Press, 2002

[18] G.R. Pierce, B.R. Sarason, and I.G.Sarason. Handbook of Social Support and the Family: The Plenum Series on Stress and Coping. New York: Plenum Press, 1996

[19] G.D. Zimet, N.W. Dahlem, S.G. Zimet, and G.K. Farley. "The Multidimensional Scale of Perceived Social Support." Journal of Personality Assessment, vol. 52, pp.30-41, 1988

[20] R. Schwarzer, N. Knoll, and N. Rieckmann (2004). "Social Support." internet: http://userpage.fuberlin.de/ health/support/schwarzer_knoll_rieckmann2004.pdf [Jun. 13, 2016]

[21] S. Maslihah, S. "Studi Tentang Hubungan Dukungan Sosial, Penyesuaian Sosial di Lingkungan Sekolah dan Prestasi Akademik Siswa SMPIT Assyfa Boarding School Subang Jawa Barat." Jurnal Psikologi Undip, vol.10, pp.103-114, 2011

[22] A.R. Fitri and A. Widyastuti. A. "Orang Tua yang Amanah: Tinjauan Pustaka Indijinus. “ Jurnal Psikologi Sosial, vol. 13, pp. 12-24, 2017

[23] S. Somantri, S. Psikologi Anak Luar Biasa. Bandung: PT. Refika Aditama, 2017

[24] F. Kong, K. Ding, and J. Zhao. "The Relationships Among Gratitude, Self-esteem, Social Support, and Life Satisfaction Among Undergraduate Students." Journal of Happiness Studies, vol. 16, pp. 1-13, 2014 